\title{
Corporate social responsibility and stakeholders: Review of the last decade (2006-2015)
}

\author{
Andrija Barić \\ KONČAR - Power Plant and Electric Traction Engineering Inc., Zagreb, Croatia
}

\section{Abstract}

Background: Globalization, strong development of information-communication technologies and the emergence of new burning challenges for the global communities enabled the concept of corporate social responsibility to be perceived as a business model that allows for successful differentiation of companies, as well creating sustainable competitive advantage. Objective: The goal of the paper is to offer a short overview of the role of internal and external stakeholders within the concept of corporate social responsibility and point out the importance of quality relationships between the company and its stakeholders with the aim of improving the standard of living of all community members. Methods/approach: The paper is based on a systematic analysis of previously published relevant international scientific papers in the field of corporate social responsibility, stakeholder theory and information-communication technologies. Results: This paper demonstrates that the concept of corporate social responsibility has gone, in its several decades of existence, from the "unnecessary dependency" phase to the critical business model phase. Conclusions: As there is a natural connection between the concept of corporate social responsibility and the stakeholders, it can be concluded that the quality of the relationship between the company and its stakeholders represents a key factor that affects the success of the company in its notion of differentiating itself from competitors and creating sustainable competitive advantage.

Keywords: corporate social responsibility, stakeholders, information-communication technologies, differentiation

JEL classification: M14

Paper type: Research article

Received: Jan 04, 2017

Accepted: Mar 18, 2017

Citation: Baric, A. (2017), "Corporate social responsibility and stakeholders: Review of the last decade (2006-2015)", Business Systems Research, Vol. 8, No. 1, pp. 133-146.

DOI: 10.1515/bsrj-2017-0011

\section{Introduction}

The modern world presents many different and burning challenges to the entire population of the world, as well as profit and non-profit organizations every day. The neglect of set challenges can lead to societal, economic, ecological and cultural catastrophes and change the global picture of society as we know it. In everyday 
life of undeveloped, but also developed economies, demands of community members, non-governmental organizations and government and regulative bodies for individual and organizational corporate social responsibility in the context of finding solutions to present challenges, but also to the heavy inequality of distribution of goods which developed as a consequence of the exclusive effects of market forces, are increasingly present (Bird et al., 2007). The increase of stakeholder concern for societal and environmental challenges has caused the emergence of the concept of corporate social responsibility in the 1950s as well as its strong development within scientific and business circles from 1960 onwards. As strong development continues even to this day, the complexity of the concept itself increases with equal dynamic (Brammer et al., 2012). Carroll and Shabana (2010) point out that the concept of corporate social responsibility represents an encompassing framework of different concepts that study the relationship of companies and the community in which the company operates, regardless of whether the community is local, national or global. Because the concept is highly complex, there is no unanimously accepted definition of the concept of corporate social responsibility to this day, so it is interpreted differently within the global economic network, and often by different groups of stakeholders (Dahlsrud, 2010). Even though the concept is highly complex, it also undoubtedly possesses a clear strategic determinant and represents an inseparable part of the business model of modern global corporations throughout the world today (Nielsen, Thomson, 2009).

By adequate governance of the concept of corporate social responsibility, the management can achieve better financial results and at the same time improve the community in which it operates by increasing the standard of living of the company's internal and external stakeholders (Du et al., 2011). In the late 1970s, Carroll (1979), one of the pioneers and leading global theorists of corporate social responsibility, presented the concept of corporate social responsibility that is based on: (i) economic responsibility; (ii) legal responsibility; (iii) ethical responsibility and (iiii) philanthropic responsibility. By implementing the concept of corporate social responsibility, management can ensure that business operations adhere to legal regulations and economic standards, all with the goal of building higher quality relationships with stakeholders (Piacentini et al., 2000). As it is in the nature of the concept of corporate social responsibility to conduct business within legal regulations, it can be concluded that conducting and communicating the concept of corporate social responsibility is mostly of voluntary character (Wettstein, 2009). All presented definitions of corporate social responsibility are based on the idea that emphasizes the fact that management of the company should take into account all internal and external stakeholder expectations while developing the corporate social responsibility strategy and the strategy of the company (Saeidi et al., 2015).

In the context of the connection between the concept of corporate social responsibility and the company stakeholders, it can be concluded that the concept of corporate social responsibility developed from stakeholder theory (Pirsch et al., 2007). Even though Freeman developed the foundations of the theory, Ansoff was the first to use the term stakeholder theory in 1965 (Roberts, 1992). Stakeholder theory rests on the idea that sustainability and success of a business depend on the success of the organization's management in achieving economic and societal goals through fulfilling the needs of key groups of internal and external company stakeholders (Pirsch et al., 2007). As per the stakeholder theory, Freeman (1984) described the company stakeholders as groups or individuals who are under the influence of business activities or who can influence the business operations of a 
company and fulfilment strategic goals. He pointed out that the shareholders, employees, consumers, suppliers, financial institutions, non-government groups and government institutions were the most important stakeholders of an organization (Freeman, 1984). Ullmann (1985) highlights three key factors that affect the relationship between a company and a certain group of stakeholders: (i) the power of the stakeholders, (ii) strategic orientation of management towards the concept of corporate social responsibility and (iii) former and present financial results of the company. The importance of certain groups of internal and external stakeholders for the business operations of the company changes frequently and depends on the phases of the business operations, as well as characteristics of the market and the community (Jawahar, McLaughlin, 2001).

The concept of corporate social responsibility, in times when social values change rapidly, can present the means of bringing together organizational values and values of the stakeholders. The prerequisite for the success of such a process of convergence is including the interest of the stakeholders in the socially responsible strategy that presents a key segment of the business strategy of an ever-greater number of companies (Saeed, Arshad, 2012). Within the concept of corporate social responsibility, stakeholders are portrayed as groups of persons towards whom the company's business and socially responsible activities are oriented. Today, it is almost impossible to discuss the concept of corporate social responsibility without taking note of the stakeholders of the company (Sun et al., 2010). A quality and strong relationship with stakeholders increases competitiveness because it directly improves the reputation of the company through perception of the stakeholders. Key stakeholders determine the conditions in which the company does business by creating opportunities and threats for survival and growth. For this reason, while developing strategy the management must encompass the needs, interests and motives of key stakeholders as per the concept of corporate social responsibility (Rosinka-Bukowska, Penc-Pietrzak, 2015). The quality of the corporate social responsibility strategy, and as a consequence the generation of financial and nonfinancial benefits from conducting and communicating socially responsible activities, depends directly on the success of filtering ideas and guidelines geared towards the company by the key groups of stakeholders in the communication process (Frostenson et al. 2011). Based on the aforementioned, it is concluded that there is a link between the idea of socially responsible business operations and the stakeholders of every company (Godfrey et al., 2009).

\section{Literature review}

\section{Corporate social responsibility}

Today, more so than ever before, companies implement socially responsible activities in order to ensure the survival of the global society as we know it today, all the while ensuring the sustainability and prosperity of their own business operations (Skarmeas, Leonidou, 2013). Even though the concept of corporate social responsibility originated in the developed Western democracies, today the concept itself is considered a global movement that encompasses and unifies different aspects of society, from legislative and non-governmental to the cultural and business aspects (Sriramesh et al., 2007). The rapid spread of the concept of corporate social responsibility from Western countries to countries in transition and other countries throughout the world stimulated the creation of a new dimension of corporate social responsibility, the increase in complexity, as well as further 
popularization of the concept itself (Brammer et al, 2012). It can be concluded that the concept of corporate social responsibility in the past seventy years encompassed the key problems of the global community and created perhaps the most important link between society and the business world. Besides spreading the concept on a global level and the emergence of new dimensions of corporate social responsibility, new burning problems and challenges of the global communities are additional reasons for the increasing complexity of the concept of corporate social responsibility (Moura-Leite, Padgett, 2011). In accordance with the continual increasing of complexity and ever-increasing pressure by various groups of internal and external stakeholders, achieving and sustaining responsibility towards the community is becoming an increasingly difficult process for the company's management (Carroll, Shabana, 2010).

Positioning of the company on the market, as a socially responsible organization, demands detailed knowledge of the concept of corporate social responsibility and adequate models of digital communication by the management, but also by the rest of the internal stakeholders, who are a key, reliable and transparent communication channel towards external stakeholders (Polonsky, Jevons, 2006). The success and efficacy of conducting socially responsible activities also depend on adapting the strategy of corporate communication to the rapid development of information-communication technologies as well as to the development of social networks and the Internet (Dutot et al., 2016). Digital transformation in communicating social responsibility started in the middle of the 1990s (Isenmann, 2006), and enabled the stakeholders with computer skills to easily find timely and prompt information about corporate social responsibility, but also the overall business operations of the company (Cho et al., 2009).

Apart from the simpler discovery of information related to the company's corporate social responsibility, strong development of information-communication technologies and the emergence of social networks allowed for a continuing and two-way exchange of information between individual and profit and non-profit organizations throughout the world (Bicen, Cavus, 2011). As the nature of the Internet is unpredictable and allows for a speedy transfer of information within the global community, the consequences of such two-way communication are impossible to predict or control, therefore management and internal stakeholders must be very careful in expressing personal attitudes on websites and social networks. It can be concluded that digital transformation, and consequently the emergence of websites and social networks, significantly changed the power structure in communicating corporate social responsibility between profit and nonprofit organizations and their stakeholders (Fieseler et al, 2010). Successful communication of socially responsible activities towards stakeholders enables the creation of a more positive reputation of the company. Companies with a more positive reputation achieve better results than their competition that offers products and services of similar quality and price. Positive reputation, which presents valuable immaterial assets of a company, is almost impossible to completely copy from competitors, because it is a result of a whole array of different activities, the key activities being socially responsible activities (Boyd et al., 2010).

In order for companies on domestic or global markets to successfully establish a positive reputation, it is necessary to ensure that the entire supply chain of the company operates in accordance with social and environmental standards so the stakeholders, by communicating with the company, could successfully differentiate the company from its competition (Boehe, Barin Cruz, 2010). The result of the 
differentiation of companies based on corporate social responsibility is created by building positive perception, trust and awareness in stakeholders and that process of differentiation can take several years (Barin Cruz, Boehe, 2008). For that reason, it is very difficult for competitor companies in the industry to effectively imitate the process of differentiation of a successful socially responsible company (Johansen, Ellerup Nielsen, 2012). Differentiation based on corporate social responsibility is also appropriate for smaller companies, because it does not require investing of significant financial and non-financial resources (Boulouta, Pitelis, 2014). The benefits of differentiation, based on socially responsible activities, are created directly because of the readiness of consumers to pay more for products and services that are placed on the market by socially responsible companies (Bhattacharya et al., 2008). Regardless of whether the differentiation of a company based on corporate social responsibility is achieved on organizational or lower production and service levels, the company will be able to obtain a competitive advantage and ensure stability and growth of its business operations by being a market leader (Boehe, Barin Cruz, Ogasavara, 2010).

Lee (2008) assumes that the development of the concept of corporate social responsibility, from its emergence in the 1950s until today, created two main changes within the concept itself: (i) the impact of corporate social responsibility is less often analysed on a macroeconomic level, while the analyses of the impact of socially responsible activities on the company's processes and its business operations are increasing in frequency and (ii) the concept of corporate social responsibility shifted from a distinctly ethical and philanthropic to a more business and resultsoriented approach.

Even though there are discrepancies in defining desirable levels of corporate social responsibility in business operations between the industries on the global market, corporate social responsibility is considered an imperative on the developed global market today, regardless of whether business operations of powerful corporations or small family businesses are observed. Both century-old corporations and small companies in the making are currently doing their best to satisfy the wants and needs of all key groups of stakeholders, not just shareholders, in order to maximize the triple bottom line of sustainable business (Carvalho et al., 2010).

\section{Stakeholders and their role in business}

As the interest of consumers, government bodies, non-government organizations and other groups of stakeholders for potential company contributions to the development of the community has been increasing for decades, so is the concept of corporate social responsibility gaining significance within managerial circles throughout the global economic network by the day (Skarmeas, Leonidou, 2013). Aside from the increase in the popularity of the concept in managerial circles, more and more reputable scientific institutions are including classes in their programs, which observe and research the issues of corporate social responsibility in business. Educating young people of different cultures in scientific institutions throughout the world gives additional momentum in increasing the need for socially responsible behavior of companies as well as continual care for the interests of all groups of stakeholders, not just owners (Smith, 2007). Actively tracking the interests of stakeholders and satisfying the needs of key internal and external stakeholders enables greater sustainability of business operations, greater competitive advantage and an increase in loyalty of employees and consumers (Pirsch et al., 2007). 
It can be concluded that corporate social responsibility is a concept that most thoroughly describes the connection between company and society, and within which stakeholders represent a key and unavoidable determinant (Castello Branco et al., 2014). Therefore, corporate social responsibility is described as a stakeholderfocused concept that transcends the borders of an organization, and is based on an ethical understanding of organizational responsibilities towards the influence of business activities on the society and environment (Maon et al., 2009). The concept itself consists of different dimensions of corporate social responsibility, which encompass activities geared towards different types of stakeholders (McWilliams et al., 2006). The stakeholders of a company form their perception of the company depending on their individual attitudes of corporate social responsibility and their degree of awareness of socially responsible activities conducted as part of the business processes (Pomering, Dolnicar, 2009). Freeman and coauthors (2008) divide stakeholders into primary and secondary. Primary stakeholders are the ones whose actions are of key importance to the business operations of the company, while the secondary are the stakeholders who have the possibility of influencing the perception and attitudes of primary stakeholders. Besides the aforementioned, primary stakeholders have the power and means that enable them to influence the management of the company, while secondary stakeholders do not possess the ability to approach the management as directly.

The management of an ever-increasing number of global companies is oriented on continual conducting and communicating of socially responsible activities to the local, national and global communities (Blomback, Wigren, 2009). In order for the management to obtain benefits through the differentiation achieved by a greater level of corporate social responsibility, socially responsible activities have to be adequately communicated to internal and external stakeholders through various communication channels (Bittner, Leimeister, 2011). Corporate social responsibility reports, websites, social networks and advertising all represent key communication channels of today's corporate social responsibility (Birth et al., 2008). Modern global environment and rapid development of information-communication technologies allow for less and less use of exclusive traditional channels for communicating corporate social responsibility, and demand that the management create communication strategies that encompass a combination of digital and traditional communication (Morsing, Schultz, 2006). The possibility of two-way and direct communication with internal and external stakeholders, as well as significantly lower costs than communicating by using traditional channels, urged the management to include websites and social media into the communication strategy of corporate social responsibility. Aside from profit organizations, communicating corporate social responsibility using social media and websites is also appropriate for nongovernmental organizations, consumers and various other groups of stakeholders who, by using such a communication model, can share their own thoughts and ideas with other stakeholders within a very short timeframe (Kaplan, Haenlein, 2010). Communication using social media enabled passive stakeholders to become powerful creators and transferors of information, who can now affect the reputation of the company, which in turn allows them to co-create the policy of corporate social responsibility and indirectly affect the company's business strategy (Lee et al., 2013). The rise of social media enabled an exchange of information between an individual and organizations in real time, and the popularity of using social media is rapidly increasing in all parts of the world every day. Aside from popularizing existing social media platforms, new specialized social networks that create an array of new 
possibilities for profit and non-profit organizations and stakeholders are emerging daily (Bicen, Cavus, 2011).

Besides the financial inability of certain groups of stakeholders in underdeveloped countries to reward socially responsible businesses, the increase of skepticism in certain stakeholders presents an increasingly big problem for management (Carvalho et al., 2010). In order for management to successfully prevent the appearance of skepticism in stakeholders and achieve sustainable competitive advantage through differentiation based on socially responsible activities, it is necessary to know the characteristics of key stakeholders as well as design an adequate communication strategy towards them. Sometimes a decade-long process of building a positive reputation can be destroyed in a matter of days, especially in situations where management neglects the interests of key stakeholders and thus motivates them to disclose negative attitudes towards other stakeholders in a digital global network (Vanhamme, Grobben, 2009).

\section{Methodology}

This paper functions as a brief overview of the concept of corporate social responsibility, as well as the role of the stakeholders within the concept itself, for the period between 2006 and 2015. Special attention was paid to the importance of corporate social activities that enable differentiation from competitors and creating sustainable competitive advantage. Stakeholders are viewed as key and inseparable determinants of the concept of corporate social responsibility, with a separate review of the connection between socially responsible activities and internal and external stakeholders. The paper is based on the systematic analysis of previously published relevant international scientific papers from the fields of corporate social responsibility, stakeholder theories and information-communication technologies. In the theoretical part of the paper, methods of analysis and compilation have been used in order to present the importance of the concept of corporate social responsibility within the global business and social community, as well as the influence of corporate social responsibility on the development of quality relationships with primary and secondary stakeholders. The method of deduction has been used in order to reach conclusions about the importance of the concept of corporate social responsibility for the business result of the company, and in order to ascertain the importance of stakeholders within the concept itself.

\section{Results}

\section{External stakeholders}

Socially responsible and sustainable business operations create a series of benefits for the community and the environment, but also for the company's business operations (Carvalho et al., 2010). The company, which is perceived within the community as socially responsible, has the potential to create positive reputation, more possibilities in retaining quality employees, continuing protection against risk from bad managerial governance and the ability to use new types of differentiation from the competition. Conducting, as well as adequate and transparent communicating of socially responsible activities, positively affects the satisfaction and trust of consumers, which allows them to identify with the values nurtured by the company (Martinez, del Bosque, 2013). Partial or complete adherence to the company's values and a high level of loyalty affect the willingness of the consumer to pay a higher price for the company's products and services, and therefore 
enable the generation of direct financial benefits for the company (Pirsch et al., 2007).

Peloza (2006) conducted a research according to which he points out that corporate social responsibility in business has an increasingly positive effect on the company's reputation with its stakeholders; and that such a positive reputation ensures stability and sustainability of business operations by the day, and sometimes even generates certain financial benefits. Of similar opinions are Lin and coauthors (2009), who present results through which they point out that the differentiation based on corporate social responsibility may not always increase profitability in the short them, but that it will positively affect protection from risks of bad managerial decisions, and thereby ensure existing profitability or even increase it in the long term. Therefore, an ever-increasing number of companies in the world are implementing socially responsible activities in order to obtain certain benefits and improve their reputation with external stakeholders. Besides, the vehemence of media and non-government organizations for uncovering socially irresponsible business operations has significantly increased in recent years, turning the degree of corporate social responsibility more and more into a means of positive or negative differentiation from the competition in the industry. As media coverage of socially irresponsible business operations increases, so does the number of external stakeholders who are skeptic towards conducting socially corporate activities (Skarmeas, Leonidou, 2013). Modern technology, development of the Internet and easily accessible global media space allowed the external stakeholders to not have to rely only on the media and non-government organizations when expressing attitudes about corporate social responsibility of companies, but by using websites and social media they can send short informative posts which can set off an avalanche of events that can shake the company to its core, as well as society in general (Lyon, Montgomery, 2012). Dissatisfaction of key external stakeholders in one of the markets in which the company operates can rapidly spread onto other markets, and thus endanger the business operations in markets in which the company was perceived as successful and socially responsible (Bhattacharya et al., 2008).

\section{Internal stakeholders}

Even though the concept of corporate social responsibility is primarily oriented towards external stakeholders, the organization's management must not neglect the effect of socially responsible activities on the internal stakeholders and their role in the concept. The efficacy of conducting socially responsible activities equally depends on external and internal stakeholders (Waddock, Googins, 2011). Palmer (2012) points out that the key task of the management, in the context of implementing the concept of corporate social responsibility and generating benefits, is to achieve a balance in the complex network of relationships towards stakeholders. That is not a simple task, seeing as the management is faced with the oftentimes incompatible interests of internal and external stakeholders, which sometimes makes it very hard to choose activities that will satisfy all key stakeholders (Pedersen, 2006). Aside from the positive effect on profitability and economic growth, it has been proven that the concept of corporate social responsibility positively affects the satisfaction, motivation and loyalty of employees, while allowing the management to extract the best qualities from every employee, which directly contributes to the creation of positive business trends (Torugsa et al., 2012). Ali and coauthors (2010) come to a similar conclusion, stating that a higher level of 
corporate social responsibility positively affects the loyalty of employees which significantly improves the efficacy of business processes. A greater level of motivation, loyalty and satisfaction caused by socially responsible business operations allows the employees and other internal stakeholders to identify with organizational values (Kim et al., 2010).

It can be concluded that the effects of socially responsible activities are aimed at not only the external stakeholders, but internal stakeholders of the company who act as a trustworthy communication channel towards external groups of stakeholders as well (Collier, Esteban, 2007). The concept of corporate social responsibility can be seen as an efficient tool for human resource management by using trust, satisfaction and employee motivation. It is simpler for the management to achieve sustainable competitive advantage when they are in the position to retain highly educated and motivated employees, and the concept of corporate social responsibility represents the very business model that positively contributes to a lower fluctuation of employees (Lee et al., 2013). As an increasing number of profit and non-profit organizations decides to implement socially responsible activities, situations in which partnerships are formed between entities from the profit and non-profit sectors are more and more frequent. Such partnerships, formed in order to conduct socially responsible activities between companies and non-government organizations, but other groups of stakeholders as well, enable transfer of knowledge and skills that directly improves the employees and the management (Seitanidi, Crane, 2009).

To successfully implement the concept of corporate social responsibility within an organization, it is necessary for all internal stakeholders to proactively take part in the process, both on individual and collective levels, in order for such success to improve the relationships with external stakeholders and society as well as enable the generation of financial and non-financial benefits for the company (Basu, Palazzo, 2008). Although investing in socially responsible activities most often requires initial investment of financial resources, the company has the possibility, by proper communication with its stakeholders, to achieve financial returns on investment and thus increase the value of proprietary interests in the long term (Smith, 2007). It can therefore be pointed out that the concept of corporate social responsibility has reached the phase of a critical business model in the 21st century (Palmer, 2012).

\section{Conclusion}

\section{Summary of research}

Implementation, conducting and communicating of the concept of corporate social responsibility is becoming a topic that is more and more important for the management of modern global companies. The number of internal and external stakeholders who are influenced by the level of corporate social responsibility of the company when making decisions about using their products or services is constantly increasing. For that reason, many companies use differentiation based on corporate social responsibility to obtain a sustainable competitive advantage and generate certain benefits. For the process of differentiation to be successful, the management must identify the needs and interests of key stakeholders and adapt the choice and communication of corporate social responsibility activities towards the stakeholders. It can be concluded that socially responsible business operations positively affect the company's reputation, employee motivation, consumer loyalty, protection from bad managerial decisions and long-term profitability. 


\section{Research gaps and future research recommendations}

As corporate social responsibility has been developing within the scientific world since the middle of the last century, it has become, although multi-dimensional and complex, a very elaborate concept. Seeing as there is a natural connection between the stakeholders of a company and the concept of corporate social responsibility, as well as the fact that the concept of corporate social responsibility itself developed from the stakeholder theory, the role of internal and external stakeholders within the concept has also been meticulously researched. On the other hand, it is noticeable that the analysis of the effect of corporate social responsibility on export activity and relationships with stakeholders in foreign markets is not as elaborate as it is on the domestic market. In an increasingly globalized market, in which the importance of international trade increases by the day, it would be very interesting to discover in which way the degree of corporate social responsibility affects the elimination of entry barriers in export markets, as well as export processes in general.

\section{Research limitations}

This paper is based exclusively on secondary data and available international scientific literature. Quality of the research would be much greater if the research had been conducted by using a questionnaire or interview with persons in companies who are familiar with overall business operations and the aspect of corporate social responsibilities in business. By using the primary research approach it would be possible to generate higher quality results and a more complete image for the reader.

\section{References}

1. Ali, I., Rehman, K.U., Ali, S.I., Yousaf, J., Zia, M. (2010), "Corporate social responsibility influences, employee commitment and organizational performance", African journal of Business management, Vol. 4 No. 13, pp. 2796.

2. Barin Cruz, L., Boehe, D. M. (2008), "CSR in the global market place: Towards sustainable global value chains", Management Decision, Vol. 8 No. 46, pp.11871209.

3. Basu, K., Palazzo, G. (2008), "Corporate social responsibility: A process model of sensemaking", Academy of Management Review, Vol. 33 No. 1, pp. 122-136.

4. Bhattacharya, C. B., Sen, S., Korschun, D. (2008). Using Corporate Social Responsibility to Win the War for Talent.

5. Bicen, H., Cavus, N. (2011), "Social Network Sites Usage Habits of Undergraduate Students: Case Study of Facebook", Procedia-Social and Behavioral Sciences, Vol. 28, pp. 943- 947.

6. Bird, R., Hall, A. D., Momente, F., Reggiani, F. (2007), "What corporate social responsibility activities are valued by the market?", Journal of Business Ethics, Vol. 76 No. 2, pp. 189-206.

7. Birth, G., Illia, L., Lurati, F., Zamparini, A. (2008), "Communicating CSR: practices among Switzerland's top 300 companies", Corporate Communications: An International Journal, Vol. 13 No. 2, pp. 182 - 196.

8. Bittner, E. A. C., Leimeister, J. M. (2011). Towards CSR 2.0-Potentials and Challenges of Web 2.0 for Corporate Social Responsibility Communication. 
9. Blomback, A., Wigren, C. (2009), "Challenging the importance of size as determinant for CSR activities", Management of Environmental Quality: An International Journal, Vol. 30 No. 3, pp. 256-270.

10. Boehe, D. M., Cruz, L. B. (2010), "Corporate social responsibility, product differentiation strategy and export performance", Journal of Business Ethics, Vol. 91, pp. 325-346.

11. Boehe, D. M., Cruz, L. B., Ogasavara, M. H. (2010). How can Firms from Emerging Economies Enhance their CSR-Supported Export Strategies? Insper, Ibmec, São Paulo.

12. Boulouta, I., Pitelis, C.N. (2014), "Who needs CSR? The impact of corporate social responsibility on national competitiveness", Journal of Business Ethics, Vol. 119 No. 3, pp. 349-364.

13. Boyd, B. K., Bergh, D. D., Ketchen Jr, D. J. (2010), "Reconsidering the reputationperformance relationship: A resource-based view", Journal of management, Vol. 36 No. 3, pp. 588-609.

14. Brammer, S., Jackson, G., Matten, D. (2012), "Corporate social responsibility and institutional theory: new perspectives on private governance", Socio-Economic Review, Vol.10 No. 1, pp. 3-28.

15. Carroll, A.B. (1979), "A three-dimensional conceptual model of corporate performance", Academy of Management Review, Vol. 4 No. 4, pp. 497-505.

16. Carroll, A. B., Shabana, K. M. (2010), "The business case for corporate social responsibility: a review of concepts, research and practice", International Journal of Management Reviews, Vol. 12 No. 1, pp. 85-105.

17. Carvalho, S.W., Sen, S., de Oliveira Mota, M., de Lima, R.C. (2010), "Consumer reactions to CSR: A Brazilian perspective", Journal of Business Ethics, Vol. 91, pp. 291-310.

18. Castelo Branco, M., Delgado, C., Sá, M., Sousa, C. (2014), "Comparing CSR communication on corporate web sites in Sweden and Spain", Baltic Journal of Management, Vol. 9, No. 2, pp. 231-50.

19. Cho, C. H., Phillips, J. R., Hageman, A. M., Patten, D. M. (2009), "Media richness, user trust, and perceptions of corporate social responsibility", Accounting, Auditing \& Accountability Journal, Vol. 22 No. 6, pp. 933-952.

20. Collier, J., Esteban, R. (2007), "Corporate social responsibility and employee commitment", Business Ethics: A European Review, Vol. 16 No. 1, pp. 19-33.

21. Dahlsrud, A. (2008), "How corporate social responsibility is defined: An analysis of 37 definitions", Corporate Social Responsibility and Environmental Management, Vol. 15 No. 1, pp. 1-13.

22. Du, S., Bhattacharya, C. B., Sen, S. (2011), "Corporate social responsibility and competitive advantage: Overcoming the trust barrier", Management Science, Vol. 57 No. 9, pp. 1528-1545.

23. Dutot, V., Lacalle Galvez, E., Versailles, D. W. (2016), "CSR communications strategies through social media and influence on e-reputation", Management Decision, Vol. 54 No. 2, pp. 363-389.

24. Fieseler, C., Fleck, M., Meckel, M. (2010), "Corporate social responsibility in the blogosphere. Journal of Business Ethics, Vol. 91 No. 4, pp. 599-614.

25. Freeman, R. E. (1984). Strategic Management: a Stakeholder Approach. Marshall, MA/Pitman.

26. Freeman R. E., Harrison J. S., Wicks A. (2008). Managing for Stakeholders: Survival, Reputation, and Success. Yale University Press: New Haven, CT. 
27. Frostenson M, Helin S, Sandström J. (2011), "Organising Corporate Responsibility Communication Through Filtration: A Study of Web Communication Patterns in Swedish Retail", Journal of Business Ethics, Vol. 100 No. 1, pp. 31-43.

28. Godfrey, P.C., Merrill, C.B., Hansen, J.M. (2009), "The relationship between corporate social responsibility and shareholder value: An empirical test of the risk management hypothesis", Strategic management journal, Vol. 30 No. 4, pp.425445.

29. Isenmann, R. (2006), "Internet-based communication", in Jonkor, J., de Witte, M. (eds). Management Models for CSR, Berlin: Springer, pp. 247-256.

30. Jawahar, I. M., McLaughlin, G.L. (2001), "Toward a Descriptive Stakeholder Theory: An Organizational Life Cycle Approach", Academy of Management Review, Vol. 26 No. 3, pp. 397-415.

31. Johansen, T. S., Ellerup Nielsen, A. (2012), "CSR in corporate self-storyinglegitimacy as a question of differentiation and conformity", Corporate communications: an international journal, Vol. 17 No. 4, pp.434-448.

32. Kaplan, A. M., Haenlein, M. (2010), "Users of the world, unite! The challenges and opportunities of social media", Business Horizons, Vol. 53 No. 1, pp. 59-68.

33. Kim, H.R., Lee, M., Lee, H.T., Kim, N.M. (2010), "Corporate social responsibility and employee-company identification", Journal of Business Ethics, Vol. 95 No. 4, pp. 557-569.

34. Lee, K., Oh, W., Kim, N. (2013), "Social media for socially responsible firms. Analysis of Fortune 500's Twitter profiles and their CSR/CSIR ratings", Journal of Business Ethics, Vol. 118 No. 4, pp. 791-806.

35. Lee, M.P. (2008), "A review of the theories of corporate social responsibility: its evolutionary path and the road ahead", International Journal of Management Reviews, Vol. 10 No. 1, pp. 53-73.

36. Lin, C.H., Yang, H.L., Liou, D.Y. (2009), "The impact of corporate social responsibility on financial performance: Evidence from business in Taiwan", Technology in Society, Vol. 31 No.1, pp.56-63.

37. Lyon, T. P., Montgomery, A. W. (2012). Tweetjacked: The impact of social media on corporate Greenwash. Working paper. University of Michigan.

38. Maon, F., Lindgreen, A., Swaen, V. (2010), "Organizational stages and cultural phases: A critical review and a consolidative model of corporate social responsibility development", International Journal of Management Reviews, Vol.12 No. 1, pp. 20-38.

39. Martínez, P., del Bosque, I.R. (2013), "CSR and customer loyalty: The roles of trust, customer identification with the company and satisfaction", International Journal of Hospitality Management, Vol. 35, pp. 89-99.

40. McWilliams, A., Siegel, D.S., Wright, P.M. (2006), "Corporate social responsibility: strategic implications", Journal of Management Studies, Vol. 43 No. 1, pp. 2-17.

41. Morsing, M., Schultz, M. (2006), "Corporate social responsibility communication: stakeholder information, response and involvement strategies", Business Ethics: A European Review, Vol. 15 No. 4, pp. 323-338.

42. Moura-Leite, R. C., Padgett, R. C. (2011), "Historical background of corporate social responsibility", Social Responsibility Journal, Vol. 7 No. 4, pp. 528-539.

43. Nielsen, A. E., Thomson, C. (2009), "Investigating CSR communication in SMEs: a case study among Danish middle managers", Business Ethics: A European Review, Vol. 18 No. 1, pp. 83-93. 
44. Palmer, J. H. (2012). Corporate Social Responsibility and Financial Performance: Does it Pay to Be Good? Claremont McKenna College, CMC Senior Theses, Paper 529.

45. Pedersen, E. R. (2006), "Making Corporate Social Responsibility (CSR) Operable: How Companies Translate Stakeholder Dialogue into Practice", Business and Society Review, Vol. 111 No. 2, pp. 137-163.

46. Peloza, J. (2006), "Using corporate social responsibility as insurance for financial performance", California Management Review, Vol. 48 No. 2, pp. 52-72.

47. Piacentini, M. G., MacFadyen L., Eadie D. R. (2000), "Corporate social responsibility in food retailing", International Journal of Retail and Distribution Management Vol. 28 No. 10, pp. 459-469.

48. Pirsch, J., Gupta, S., Grau, S. L. (2007), "A framework for understanding corporate social responsibility programs as a continuum: An exploratory study", Journal of business ethics, Vol. 70 No. 2, pp.125-140.

49. Polonsky, M. J., Jevons, C. (2006), "Understanding issue complexity when building a socially responsible brand", European Business Review, Vol. 18 No. 5, pp. 340349.

50. Pomering, A., Dolnicar, S. (2009), "Assessing the prerequisite of successful CSR implementation: Are consumers aware of CSR initiatives?", Journal of Business Ethics, Vol. 85, pp. 295-301.

51. Roberts, R.W. (1992), "Determinants of corporate social responsibility disclosure", Accounting, Organizations and Society, Vol. 17 No. 6, pp. 595-612.

52. Rosińska-Bukowska, M., Penc-Pietrzak, I. (2015), "Corporate social responsibility in corporate strategy in the globalised economy", Administracja i Zarzadzanie, Vol. 33 No. 106, pp. 195-208.

53. Saeed, M., Arshad, F. (2012), "Corporate social responsibility as a source of competitive advantage: The mediating role of social capital and reputational capital", Database Marketing \& Customer Strategy Management, Vol. 19 No. 4, pp. 219-232.

54. Saeidi, S. P., Sofian, S., Saeidi, P., Saeidi, S. P., Saeaeidi, S. A. (2015), "How does corporate social responsibility contribute to firm financial performance? The mediating role of competitive advantage, reputation, and customer satisfaction", Journal of Business Research, Vol. 68 No. 2, pp. 341-350.

55. Seitanidi, M. M., Crane, A. (2009), "Implementing CSR through partnerships: Understanding the selection, design and institutionalisation of nonprofit-business partnerships", Journal of business ethics, Vol. 85 No. 2, pp.413-429.

56. Skarmeas, D., Leonidou, C. N. (2013), "When consumers doubt, watch out! The role of CSR scepticism", Journal of Business Research, Vol. 66 No. 10, pp.18311838.

57. Smith, A.D. (2007), "Making the case for the competitive advantage of corporate social responsibility", Business Strategy Series, Vol 8. No. 3, pp. 186 - 195.

58. Sriramesh, K., Ng, C. W., Soh, T. T., Luo, W. (2007), "Corporate social responsibility and public relations: Perceptions and practices in Singapore", in May, S., Cheney, G. Roper, J. (eds). The debate over corporate social responsibility, New York: Oxford University Press, pp. 119-134.

59. Sun, N., Salama, A., Hussainey, K., Habbash, M. (2010), "Corporate environmental disclosure, corporate governance and earnings management", Managerial Auditing Journal, Vol. 25 No. 7, pp. 679-700.

60. Torugsa, N. A., O'Donohue, W., Hecker, R. (2012), "Capabilities, proactive CSR and financial performance in SMEs: Empirical evidence from an Australian 
manufacturing industry sector", Journal of Business Ethics, Vol. 109 No. 4, pp.483500.

61. Ullmann, A. A. (1985), "Data in search of a theory: A critical examination of the relationships among social performance, social disclosure, and economic performance of US firms", Academy of management review, Vol. 10 No. 3, pp. 540-557.

62. Vanhamme, J., Grobben, B. (2009), "“Too good to be true!". The effectiveness of CSR history in countering negative publicity", Journal of Business Ethics, Vol. 85, pp. 273-283.

63. Waddock, S., Googins, B. K. (2011), "The paradoxes of communicating corporate social responsibility", in Ihlen, Ø., Bartlett, J. L., May, S. (eds). The Handbook of Communication and Corporate Social Responsibility, New York: Wiley, pp. 23-43.

64. Wettstein, F. (2009), "Beyond voluntariness, beyond CSR: Making a case for human rights and justice", Business and Society Review, Vol. 114 No. 1, pp.125152.

\section{About the author}

Andrija Baric graduated from the Faculty of Economics and Business in Zagreb, Republic of Croatia, with master degree in finance. He is currently working in KONČAR - Power Plant and Electric Traction Engineering Inc. as head of department, and is currently a doctoral student at Faculty of Economics and Business, Zagreb, Republic of Croatia. His main research is corporate social responsibility in export process. Author can be contacted at andrija.baric@koncarket.hr 